\title{
Foods of Primary Consumers on Cold Desert Shrub-Steppe of Southcentral Idaho
}

\author{
MARK K. JOHNSON
}

\begin{abstract}
Trophic relationships of rabbits, black-tailed jack rabbits, pronghorn, sheep, and cattle were examined on the Idaho National Engineering Laboratory Site in southcentral Idaho. Grasses were the most important foods of lagomorphs and livestock. Pronghorn depended mostly on basin big sagebrush, common winterfat, and saltbushes. If jack rabbits increase in the future, severe competition for forage with livestock may result.
\end{abstract}

Large portions of the shrub-steppe of Idaho are winter grazed by sheep (Ovis aires), cattle (Bos taurus), and native wild herbivores. Unregulated grazing can lead to poor range condition, poor condition of wild herbivores, and poor livestock performance. Range managers must assess quantitatively the combined impacts of different herbivores on range resources before planning grazing operations.

The Idaho National Engineering Laboratory (INEL) Site in southcentral Idaho is managed by the U.S. Department of Energy and the U.S. Bureau of Land Management lets grazing leases for about $60 \%$ of the area (Johnson 1978). Sheep and cattle use these areas and each grazes in common with wild herbivores but the domestic animals do not use the same areas. The most important wild herbivores on the site are pronghorn (Antelocapra americana) and rabbits (Sylvilagus spp). Blacktailed jack rabbit (Lepus californicus) populations may become periodically important. During the present study jack rabbit population densities were extremely low on the study area.

The purpose of this paper is to report potential levels of diet competition between herbivores which use the INEL Site. Since the study area is typical of the shrub-steppe of southern Idaho, the results of this study have potential for guiding range management over wide areas of the northern Great Basin area.

\section{Study Area}

The INEL Site occupies about 231,500 ha of the upper Snake River Plain in portions of Clark, Bingham, Jefferson, Butte, and Bonneville counties, Idaho. The large area needed for isolation of nuclear facilities provided a unique, large area situated in a northern cold desert shrub habitat. The climate of the area is characterized by hot summers and cold winters. Annual precipitation is about 18 to $20 \mathrm{~cm}$ (7-8 inches) (Atwood 1970). Between 1950 and 1977 the recorded extremes were $36.6 \mathrm{~cm}$ ( 14.4 inches) and $11.4 \mathrm{~cm}$ (4.5 inches) Harniss and West 1973).

Soils are generally shallow and textures range from clays to sandy

The author is assistant professor, Department of Wildlife and Fisheries, Mississippi State University, Mississippi 39762. This report represents a portion of a PhD dessertation project conducted with the Range Science Department, Colorado State University, Fort Collins.

The project was supported in part by the U.S. Department of Energy, Idaho National Engineering Laboratory Ecology Project under contract EY-76-S-07-1526 with Colorado State University. The author expresses appreciation to T. Foppe and M. Gilbert for technical assistance in the laboratory.

Manuscript received July 17, 1978 loams. Large portions of the site are covered by basalt flows and many of the soils tend to be gravelly to rocky (Chugg et al. 1968).

Vegetation is characteristic of a northern cold shrub biome. Plant taxa extant of the INEL Site have been described by Atwood (1970) and 10 major vegetational associations have been mapped (Harniss and West 1973). Most of the area is dominated by basin big sagebrush (Artemisia tridentata) associations. Primary understory species are Indian ricegrass (Oryzopsis hymenoides), bottlebrush squirreltail (Sitanion hystrix), wheatgrasses (Agropyron spp.), common winterfat (Eurotia lanata), and bluebunch wheatgrass (Agropyron spicatum) (Harniss and West 1973). Crested wheatgrass (A. desertorum) was planted on the fringes of the INEL Site where sagebrush was chained.

Current uses of the INEL Site include environmental research, livestock grazing, and the activities of reactor facilities. Sheep and cattle are only allowed in peripheral portions of the INEL Site. Livestock have not been allowed in some central areas of the INEL Site for more than 20 years.

\section{Methods and Procedure}

Fecal materials from cattle were collected from four different areas along the western portion of the INEL Site. From each area about one gram of material was collected from each of 50 different cow chips and these materials were placed together to form a composite sample. At least 50 different sheep pellets were collected for making composite samples from each of four different areas grazed by sheep. Sheep grazed areas in all portions of the INEL Sitc where grazing was allowed, and on the western border sheep allotments were between cattle allotments so that grazing occured on a variety of habitats as it did for cattle grazing. Cattle and sheep grazed generally in the area during late winter and spring but some grazing occurred in the fall. From January through March (winter) 1976, at least 50 different pronghorn pellet groups were placed together to form a composite sample for each of seven different sites. All winter samples were from areas grazed by sheep. During July 1976 (summer) composite samples of pronghorn pellets were made in similar manner from 17 different sites. Rabbit fecal pellets were collected from 12 areas and jack rabbit fecal pellets were collected from six areas in July 1976. Summercollected samples from pronghorn and lagomorphs were taken from areas were sheep and cattle grazed, as well as from areas where no grazing was allowed. The lagomorph fecal pellets were randomly collected without regard for age. Since lagomorph fecal pellets can last for years in arid environments (Flinders and Crawford 1977), these samples roughly represent an annual dietary for lagomorphs using the INEL Site. On one sheep bedding ground fecal pellets were present where no sheep had been since 1974, supporting the contention that decomposition is very slow on the INEL Site. Since all of these herbivores are highly mobile, the areas where they defecate may differ from whcre they feed. Therefore, no attempt was made to describe vegetational aspects of each collection site. Since pronghorn are free ranging and grazing allotments are large (hundreds of hectares), it is obvious that pronghorn and livestock have daily access to many different vegetational associations, while lagomorphs are exposed to fewer different areas. All fecal samples collected for this study were taken from areas of basin big sagebrush associations. 
Anthony and Smith (1974) reported that a sample of 15 pellets appeared adequate for describing a deer diet. There is no reason to suspect that the 50 samples used to make each composite for the present study were not adequate for estimating the diets of herbivores. Although the composition of fecal material may not be identical to the dietary of a herbivore, botanical compositions of hand mixtures were not significantly different from digested residues for reindeer (Rangifer sp.), cattle, and bison (Bison bison) (Dearden et al. 1975). Rumen versus fecal contents of bighorn (Ovis sp.) and deer were similar regardless of digestive processes (Todd and Hansen 1973). I am confident that fecal contents accurately represent the dietary of herbivores studied here.

Botanical compositions of herbivore diets were determined by microscope analysis of composited fecal material. The analysis technique was the same as that reported by Sparks and Malechek (1968). Microscope fields were examined for plant fragments at $100 \times$ under a binocular microscope. Five slides were made per composited fecal sample and 20 fields were examined on each slide, so that 100 fields were quantified for each composite. There were 5,600 microscope fields quantified during the study. Westoby et al. (1976) reported that microscope analysis of materials in stomachs was not accurate for animals that browse desert shrubs. However, their technicians had less than a year of training. Technicians with more than 5 years were used to perform analysis for the present study and were trained to estimate plant compositions so that results fell within $5 \%$ of the actual percentage of any plant in a mixture. In tests, technicians were able to reliably distinguish and quantify species such as rubber rabbitbrush (Chrysothamnus nauseousus) versus douglas rabbitbrush (C. viscidiflorus), and desert wheatgrass versus bottle- brush squirreltail, which Westoby's workers could not distinguish.

Dietary similarity was indexed using Kulczynski's formula (Oosting 1956:77). Trophic diversity was calculated with Shannon's formula (Hurtubia 1973:885). Spearman's rank correlation coefficient (Snedecor and Cochran 1973-1974) was used to indicate where the degree of diet similarity was significantly high. Statistical significance was accepted at the 5\% level unless otherwise indicated. Data in this paper are means \pm standard errors unless otherwise indicated. Names of plants follow the recommendations of Beetle (1970).

\section{Results and Discussion}

Although livestock grazing occurred on separate allotments, the similarity of sheep and cattle diets was $78 \%$, indicating that there would be a high potential for competition if animals grazed on the same range. Most of the overlap was caused by common use of cheatgrass brome ( $\simeq 25 \%$ each), needleandthread (Stipa comata) $(\simeq 10 \%$ each), and common winterfat $(>25 \%$ each). Cattle and sheep used significant amounts of wheatgrass $(\simeq 11 \%$ and $24 \%$, respectively) and both herbivores used small amounts of a variety of forbs (Table 1). In the Great Basin sheep and cattle on sagebrush range often eat many of the same foods (Cook 1954: Olsen and Hansen 1977). Cattle seem to prefer grasses regardless of the range they graze (Julander 1955; Hansen and Reid 1975; Hansen and Gold 1977). Sheep are generally more selective than cattle (Olsen and Hansen 1977), but during spring sheep use many young, succulent grasses

Table 1. Average ( $\pm \mathrm{SE})$ relative densities $(\%)$ of plant fragments in feces of 5 different herbivores from the National Engineering Laboratory Site.

\begin{tabular}{|c|c|c|c|c|c|c|}
\hline \multirow[b]{2}{*}{ Plant taxa ${ }^{1}$} & \multirow[b]{2}{*}{$\begin{array}{l}\text { Cow } \\
\text { (4 sites) }\end{array}$} & \multirow[b]{2}{*}{$\begin{array}{l}\text { Sheep } \\
\text { (4 sites) }\end{array}$} & \multicolumn{2}{|c|}{ Pronghom } & \multirow[b]{2}{*}{$\begin{array}{l}\text { Rabbit } \\
\text { (18 sites) }\end{array}$} & \multirow{2}{*}{$\begin{array}{c}\text { Black-tailec } \\
\text { jack rabbit } \\
\text { (6 sites) }\end{array}$} \\
\hline & & & $\begin{array}{l}\text { Winter } \\
\text { (7 sites) }\end{array}$ & $\begin{array}{l}\text { Summer } \\
\text { (17 sites) }\end{array}$ & & \\
\hline \multicolumn{7}{|l|}{ Wheatgrasses } \\
\hline (Agropyron spp) & $10.5 \pm 3.1$ & $23.5 \pm 18.7$ & $0.1 \pm 0.1$ & $0.1 \pm 0.1$ & $18.0 \pm 5.9$ & $36.7 \pm 27.6$ \\
\hline \\
\hline \multicolumn{7}{|l|}{ Bluegrasses } \\
\hline (Poa spp) & & & & $0.4 \pm 0.3$ & $10.4 \pm 3.5$ & $19.1 \pm 16.8$ \\
\hline $\begin{array}{r}\text { Needleandthread } \\
\text { (Stipa comata) }\end{array}$ & $11.8 \pm 7.3$ & $9.8 \pm 6.9$ & & $0.1 \pm 0.1$ & $12.2 \pm 5.0$ & $0.3 \pm 0.2$ \\
\hline \multicolumn{7}{|l|}{ Indian ricegrass } \\
\hline \multicolumn{4}{|l|}{ Common winterfat } & $0.2-0.2$ & $7.6 \pm 2.8$ & $7.1 \pm 6.5$ \\
\hline (Eurotia lanata) & $29.4 \pm 18.5$ & $25.5 \pm 28.7$ & $11.1 \pm 10.0$ & $18.9 \pm 10.1$ & $5.6 \pm 5.5$ & $8.8 \pm 8.0$ \\
\hline \multicolumn{7}{|l|}{ Basin big sagebrush } \\
\hline \multicolumn{7}{|l|}{ Vetches } \\
\hline (Astragalus spp) & $0.4 \pm 0.5$ & $11.1 \pm 7.3$ & $0.2 \pm 0.2$ & $16.7 \pm 6.7$ & $7.8 \pm 3.8$ & $4.0 \pm 4.4$ \\
\hline \multicolumn{7}{|l|}{ Munro globemallow } \\
\hline \multicolumn{7}{|l|}{$\begin{array}{l}\text { Plains pricklypear } \\
\text { Ploa) }\end{array}$} \\
\hline (Opuntia polyacantha) & $0.4 \pm 0.3$ & $1.6 \pm 1.6$ & & $8.3 \pm 3.6$ & $3.7 \pm 1.2$ & $0.2 \pm 0.2$ \\
\hline \multicolumn{7}{|l|}{ Phlox } \\
\hline (Phlox spp) & $0.5 \pm 0.6$ & $0.5 \pm 0.6$ & & $0.6 \pm 0.3$ & $<0.1$ & \\
\hline Fleabanes & & & & $5.3 \pm 2.9$ & $0.7 \pm 0.5$ & $2.2 \pm 2.2$ \\
\hline \multicolumn{7}{|l|}{ Spiny hopsage } \\
\hline \multirow{2}{*}{\multicolumn{7}{|c|}{$\begin{array}{c}\text { (Grayia spinosa) } \\
\text { Bottlebrush squirreltail }\end{array}$}} \\
\hline & & & $1.5 \pm 1.5$ & $0.1 \pm 0.1$ & & \\
\hline $\begin{array}{l}\text { Pinnate transymustard } \\
\text { (Descurania pinnata) }\end{array}$ & & & & $3.1 \pm 1.3$ & & \\
\hline Douglas rabbitbrush & & & & & & \\
\hline (Chrysothamnus viscidiflorus) & $0.4 \pm 0.3$ & $0.2 \pm 0.2$ & $0.7 \pm 0.6$ & $0.9 \pm 0.4$ & & \\
\hline
\end{tabular}

${ }^{1}$ Other taxa identified in trace $(<2 \%)$ amounts were prairie junegrass (Koeleria cristata), sand dropseed (Sporbolus cryptandrus), sixweekgrass (Vulpia octoflora), douglas sedge (Carex douglasi) buckwheats (Erigonum spp), Hawk's beard (Crepis sp), common russianthistle (Salsola kali), common yarrow (Achillea millifolium), thorn skeletonplant (Lygodesmia spinosa), wallflowers (Drysimum spp), russian olive (Eleagnus angustifolia), redstem filaree (Erodium cicutarium), beardtongue (Pentstemon sp), granite pricklygilia (Leptodactylon pungens), arrowleaf balsamroot (Balsamorhiza saggitata), greasewood (Sarcobatus vermiculatus), field bindweed (Convolvulus arvensis), Indian paintbrush (Castillija angustifolia) goosefoot (Chenopodium sp), and anthropods. 
(Pechanec 1949; Thetford et al. 1971). My findings were similar to those reported by other authors and many of the plants eaten by livestock on the INEL Site were the same as those eaten elsewhere.

Pronchorn diet diversity was greater in summer (2.22) than in winter (1.14). Diets were similar to those reported by Olsen and Hansen (1977) for pronghorn in the Red Desert of Wyoming. The new, succulent growth of many species is taken by pronghorn (Table 2); but as these plants mature, food habits of pronghorn on the INEL Site apparently shift primarily to sagebrush and saltbushes as in the Red Desert. However, on the INEL Site significant amounts of common winterfat are also taken. Some pellets collected in northern portions of the study area where there are a few large pure stands of common winterfat were found to contain only parts from this plant. At least some pronghorn were feeding extensively in these areas. Whether this species is a more important winter food for certain individuals than sagebrush or saltbushes in unknown. However, common winterfat was also important summer food, as was sagebrush. Other foods that were important in the summer diet were vetches, munro globemallow (Sphaeralcea munroana), and plains pricklypear (Opuntia polyacantha). Pronghorn diets were not very similar to those of sheep and cattle, indicating that the proper use of native range by livestock should not interfere with forages preferred by pronghorn.

Table 2. Percentage similarity and Spearman's rank correlation coefficients for herbivore diets from the Idaho National Engineering Laboratory Site.

\begin{tabular}{lccc}
\hline & Percentage & \multicolumn{2}{c}{ Spearman's } \\
\cline { 3 - 4 } Diet Comparison & similarity & RHO & $\mathrm{p}^{1}$ \\
\hline Sheep vs cattle & 78 & +0.82 & 0.001 \\
Sheep vs rabbit & 56 & +0.58 & 0.020 \\
Sheep vs jack rabbit & 45 & +0.48 & 0.090 \\
Sheep vs. pronghorn-(summer) & 33 & +0.29 & 0.114 \\
Sheep vs pronghorn-(winter) & 14 & -0.05 & 0.400 \\
Cow vs rabbit & 51 & +0.49 & 0.030 \\
Cow vs jack rabbit & 35 & +0.25 & 0.200 \\
Cow vs pronghorn-(summer) & 24 & +0.24 & 0.162 \\
Cow vs pronghorn-(winter) & 15 & +0.02 & 0.397 \\
Rabbit vs pronghorn-(summer) & 36 & +0.13 & 0.330 \\
Jack rabbit vs pronghorn- & & & \\
$\quad$ (summer) & 26 & -0.03 & 0.395 \\
Rabbit vs pronghorn-(winter) & 13 & 0.00 & 0.398 \\
Jack rabbit vs pronghorn- & & & \\
$\quad$ (winter) & 11 & -0.14 & 0.337 \\
- & & & \\
\hline
\end{tabular}

' Low values $(<0.10)$ indicate that diets are significantly similar.

A wide variety of plants have been reported in the diets of rabbits (Turkowski 1975; Hansen and Gold 1977). On the INEL Site rabbits consumed mostly grasses, although a variety of shrubs and forbs were also eaten. Diet overlaps with livestock were $56 \%$ for sheep and $51 \%$ for cattle. Obviously, depending on stocking rates, serious competition could occur since livestock graze the INEL during spring to take advantage of young, succulent grasses. Nuttall cottontail (S. nuttallii) and pygmy rabbit ( $S$. idahoensis) are both present on the study area. but only one sample collected in this study was taken in the vicinity of a pygmy rabbit colony. Therefore, most of the pellets used in diet analysis were from nuttall cottontails. Analysis of food habits data for pygmy rabbits on the INEL Site indicates that this species is a heavy user of sagebrush leaves (Doug Wilde, personal communication). Although I did not find high dietary overlap between pronghorn and rabbit (13\% winter and $30 \%$ summer), similarities between pygmy rabbit and prong- horn diets may be much higher, especially in winter. However, the abundance of sagebrush on the study area suggests that the species would not interfere with each other when seeking food More research is needed to study relationships between these native herbivores.

The majority of plant fragments identified in jack rabbit feces were from grasses, but a variety of other plants were taken. Some of the grasses taken were the same as those reported from other areas (Currie and Goodwin 1966; Hayden 1966; Sparks 1968). The authors reported strong seasonal shifts in jack rabbit food preferences, and Hayden (1966) suggested that in desert areas preferences were strongly influenced by the need to maintain water balance. Certain of the succulent plants taken by jack rabbits on the INEL Site, such as plains pricklypear, may be seasonally very important to jack rabbits even though they are a minor component of the annual diet. Forbs such as common winterfat and munro globemallow each made up $8 \%$ of the annual diet of jack rabbits and were responsible for significant similarities in diets of jack rabbits and the other herbivores. Use of grasses, however was the major similarity in the diet of jack rabbits and that of the other herbivores.

The greatest potential for serious competition between herbivores on the INEL Site is during spring when young grasses are more abundant. After this period livestock are moved to summer ranges. Since cattle and sheep graze on different allotments and since pronghorn food habitats are so different from those of the other herbivores, concern on the INEL Site should be mainly for competition between lagomorphs and livestock. Rabbits require cover for protection from predators. On the INEL Site rocky, basalt outcrops in the central area provide this cover, but these outcrops are few in the areas where livestock are grazed (Johnson 1978). As long as livestock grazing is prohibited from the center of the INEL Site, competition between rabbits and livestock can not be considered a problem. Jack rabbits are not restricted to this protective cover and, therefore, might pose a serious threat to livestock operations if they become abundant.

Use of range without deterioration is possible only with careful management for proper grazing pressure so that enough forage is available for animals. Estimation of proper stocking rates is often based on relative intake rates of the different herbivores. An average black-tailed jack rabbit uses about 0.1 $\mathrm{kg}$ of dry forage per day (Cavender and Hansen 1970) and an average cottontail consumes about $0.02 \mathrm{~kg}$ per day (Hansen and Gold 1977). A range cow $(454 \mathrm{~kg})$ and a range ewe $(34 \mathrm{~kg})$ consume about $13.5 \mathrm{~kg}$ and $1.4 \mathrm{~kg}$ of dry forage per day, respectively (Cook 1970). If each species of herbivore ate the same foods, equivalent numbers of animals could be estimated by dividing the intake rate of one animal by the intake rate of another. These animals do not feed identically and calculations must account for differences in diets. Animal equivalents should be estimated according to:

$\begin{aligned} & \text { Higher Intake } \\ & \text { Rate per Animal } \\ & \text { Lower Intake }\end{aligned} \times \frac{1}{\text { Rate per Animal }} \begin{gathered}\text { fractional diet } \\ \text { similarity }\end{gathered}=\begin{aligned} & \text { Number of smaller } \\ & \text { herbivores that } \\ & \text { consume forage } \\ & \text { equivalent to that } \\ & \text { of one of the larger } \\ & \text { herbivore. }\end{aligned}$

Using this rationale about 31 black-tailed jack rabbits are equivalent to 1 range ewe and about 392 are equivalent to 1 range cow on the INEL Site (Table 3). For rabbits about 1350 are equivalent to a range cow and about 119 are equivalent to a range ewe. My result is similar to the report of Vorhies and Taylor (1933) that about 30 black-tailed jack rabbits were 
Table 3. Approximate number of rabbits and black-tailed jack rabbits which remove the same forage as a $454-\mathrm{kg}$ range cow or a $34-\mathrm{kg}$ range ewe on the INEL Site.

\begin{tabular}{lcc}
\hline & \multicolumn{2}{c}{ Equivalent } \\
\cline { 2 - 3 } Livestock species & Rabbits & Black-tailed jack rabbits \\
\hline Cow & 1350 & 392 \\
Sheep & 119 & 31 \\
\hline
\end{tabular}

equivalent to 1 sheep in Arizona, but Currie and Goodwin (1966) estimated that it only took about six black-tailed jack rabbits to remove forage for a sheep in Curlew Valley, Utah, which is less than $100 \mathrm{~km}$ south of the INEL Site. Obviously, these relationships vary among sites and the estimates reported here should not be used to generalize for other studies.

Common use of range by different herbivores can result in better use of forage and higher productivity of red meat (Cook 1954). This fact is simple when livestock producing goods for human consumption are the common users, but the evaluation of trade-offs between livestock and wildlife are not so simple. Although lagomorphs are edible, only small numbers are ever harvested for human use. On the INEL Site, sport hunting is not allowed, so that none of this production can be considered human food. Even though they are probably important ecologically and aesthetically, lagomorphs on the INEL Site may appropriately be considered as pests if their presence limits the production of goods for humans. Hansen (1972) estimated that the amount of forage consumed by jack rabbits in Colorado was sufficient to produce $\$ 7.4$ million worth of beef. Jack rabbits were rare on the INEL Site when the present study was conducted and probably did not interfere with livestock production. However, according to French et al. (1965) jack rabbit populations are cyclic on the INEL Site and once reached densities of 1.3 per ha. Using this figure for density, the potential value of forage that might be removed by jack rabbits when they are abundant on the INEL Site can be estimated from:

$\begin{aligned} & \text { No. of jack } \\ & \text { rabbits per ha }\end{aligned} \times \begin{aligned} & \text { Ha's grazed } \\ & \text { by livestock }\end{aligned} \times \begin{aligned} & \text { Intake rate } \\ & \text { of jack rabbits }\end{aligned}$
$\begin{aligned} & \text { Days of } \\ & \text { Grazing }\end{aligned} \times \frac{\mathrm{Kg} \text { of red meat }}{\mathrm{Kg} \text { of forage }} \times \begin{aligned} & \text { Value of } \\ & \text { red meat }\end{aligned}=\begin{aligned} & \text { Value of forage removed } \\ & \text { from an area by jack } \\ & \text { rabbits. }\end{aligned}$

A reasonable assumption is that $10 \mathrm{~kg}$ of forage is needed to produce $1 \mathrm{~kg}$ of red meat (Hansen 1972). Current market prices of beef and mutton are approximately 70 cents and 50 cents per $\mathrm{kg}$ live wt, respectively. Grazing is allowed to about 139,000 ha of the INEL Site, and during a population high that forage removed by jack rabbits in 3 months might be worth a little more than $\$ 40,000$ if used for production of beef or about $\$ 37,000$ if used for production of mutton. Grazing seasons and numbers of animal units per allotment on the INEL Site vary from year to year (A. Warren Ahlstrom, personal communication) so that the actual value of forage removed by jack rabbits also varies. There is no good way to estimate the amount of forage that might be available to livestock if jack rabbits did not feed during any part of the year. There are complex ecological relationships involved that are poorly understood. If jack rabbits become abundant on the study area in the future, there will be an excellent opportunity to study the actual grazing and economic relationships between these herbivores and compare results with the ideas presented here. The large numbers of lagomorphs that are equivalent to range livestock on the INEL Site suggest that control of leporids may not provide an economical way to maintain desired levels of livestock production.

Relationships between grazing animals are complex. Some of the ideas about these relationships presented here are approximations based on the best information available. There is a need to increase our understanding of grazing relationships so that management can be performed with greater precision and produce higher yields of products from the range.

\section{Literature Cited}

Anthony, R.G., and N.S. Smith. 1974. Comparison of rumen and fecal analysis to describe deer diets. J. Wildl. Manage. 38:535-540.

Atwood, N.D. 1970. Flora of the National Reactor Testing Station. Brigham Young Univ. Sci. Bull. Biol. Ser. 11(4):46 p.

Beetle, A.A. 1970. Recommended plant names. Res. Journal 31. Agr. Exp. Sta. Univ. Wyoming, Laramie. 124 p.

Cavender, B.R., and R.M. Hansen. 1970. Assimilation rates of small herbivores. Grassland Biome U.S. IBP Tech. Rep. No. 51. Colorado State Univ., Fort Collins. 7 p.

Chugg, J.C., W. Jorgenson, and M.A. Fosberg. 1968. Special soil surveyButte County. Idaho Water Resour. Board Rep. No. 5. 99 p

Cook, C.W. 1954. Common use of summer range by sheep and cattle. J, Range Manage. 7:10-13.

Cook, C.W. 1970. Energy budget of the range and range livestock. Colorado Exp. Sta. Bull. TB109, Fort Collins. 28 p.

Currie, P.O., and D.L. Goodwin. 1966. Consumption of forage by blacktailed jackrabbits of salt-desert ranges of Utah. J. Wildl. Manage.

Dearden, B.L., R.E. Pegau, and R.M. Hansen. 1975. Precision of microhistological estimates of ruminant food habits. J. Wildl. Manage. 39:402407.

Flinders, J.T., and J.A. Crawford. 1977. Composition and degradation of jackrabbit and cottontail fecal pellets, Texas high plains. J. Range Manage 30:217-220

French, N.R., R. McBride, and J. Detmer. 1965. Fertility and population density of the black-tailed jackrabbit. J. Wildl. Manage. 29:14-16.

Hansen, R.M. 1972. Estimation of herbage intake from jackrabbit feces. J. Range Manage. 25:468-471.

Hansen, R.M., and L.D. Reid. 1975. Diet overlap of deer, elk, and cattle in southern Colorado. J. Range Manage. 28:43-47.

Hansen, R.M., and I.K. Gold. 1977. Blacktail prairie dogs, desert cottontails and cattle trophic relations on shortgrass range. J. Range Manage. 30: 210-214.

Harniss, R.O., and N.E. West. 1973. Vegetation patterns of the Idaho National Reactor Testing Station, southeastern Idaho. Northwest Sci. 47:3043.

Hayden, P. 1966. Food habits of black-tailed jack rabbits in southern Nevada. J. Mammal. 47:42-46.

Hurtubia, J. 1973. Trophic diversity measurements in sympatric predatory species. Ecology. 54:885-890.

Johnson, M.K. 1978. Food hahits of coyotes in southcentral Idaho. Unpublished Ph.D. Diss. Colorado State Univ. 77 p.

Julander, O. 1955. Deer and cattle range relations in Utah. Forest Sci. 1:130139.

Olsen, F.W., and R.M. Hansen. 1977. Food relations of wild free-roaming horses to livestock and big game, Red Desert, Wyoming. J. Range Manage. 30:17-20.

Oosting, H.J. 1956. The Study of Plant Communities. W.H. Freeman and Co. San Francisco. $440 \mathrm{p}$.

Pechanec, J.F. 1949. Grazing spring-fall sheep ranges of southern Idaho. U.S Dep. Agr. Cir. No. 808. 34 p.

Snedecor, G.W., and W.G. Cochran. 1973. Statistical Methods. Iowa State Univ. Press, Ames. 593 p

Sparks, D.R. 1968. Diets of black-tailed jackrabbits on sandhill rangelands in Colorado J. Range Manage. 21:203-208.

Sparks, D.R., and J.C. Malechek. 1968. Estimating percentage dry weight in diets using a microscope technique. J. Range Manage. 21:264-265.

Thetford, F.O., R.D. Pieper, and A.B. Nelson. 1971. Botanical and chemical composition of cattle and sheep diets on pinyon-juniper grassland range. J. Range Manage. 24:425-431.

Todd, J.W., and R.M. Hansen. 1973. Plant fragments in feces of bighorns as indicators of food habits. J. Wildl. Manage. 38:363-366.

Turkowski, F.J. 1975. Dietary adaptability of the desert cottontail. J. Wildl. Manage. 39:748-756.

Vorhies, C.T., and W.P. Taylor. 1933. The life histories and ecology of jack rabbits, Lepus alleni and Lepus californicus spp., in relation to grazing in Arizona. Univ. Arizona Agr. Exp. Sta. Tech. Bull. 49:471-587.

Westoby, M., G.R. Rost, and J.A. Weis. 1976. Problems with estimating herbivore diets by microscopically identifying plant fragments from stomachs. J. Mammal. 57:167-172. 